\title{
The Benefits of the Proprioceptive Method Used in Learning English via Facebook by Thai Government Officials
}

\author{
Payung Cedar ${ }^{1} \&$ Itdharom Mitsuvan Singhara $^{2}$ \\ ${ }^{1}$ Department of English, Faculty of Humanities, Naresuan University, Phitsanulok, Thailand \\ ${ }^{2}$ Faculty of Humanities and Social Sciences, Kamphaengphet Rejabhat University, Kamphaengphet, Thailand \\ Correspondence: Payung Cedar, Department of English, Faculty of Humanities, Naresuan University, Phitsanulok, \\ Thailand 65000. Tel: 66-55-96-2028. E-mail: payungp@nu.ac.th
}

Received: June 17, 2017 Accepted: July 12, 2017 Online Published: July 14, 2017

doi: 10.5539/elt.v10n8p123 URL: http://doi.org/10.5539/elt.v10n8p123

\begin{abstract}
Good listening and pronunciation skills lead to successes in foreign language learning. The main purpose of this study was to examine the benefits of adopting the Proprioceptive Method in learning English by Thai local government officials with the help of Facebook. A seventeen-day training course was implemented, comprising two days of face-to-face training, fourteen days of online training via Facebook, and one day of course wrap-ups and evaluation. The crucial training instruments used in the study was online conversations, a minimal-pair listening test, a satisfaction survey and a Facebook chat room for participants' written comments. The statistical results showed that after the training, the trainees' ability to segment English consonant sounds that were problematic for Thais significantly increased. It is inferred that the Proprioceptive Method tended to be effective for training English via Facebook. However, looking closely to the participants' perceptions of the sounds in each pair, the rise was statistically significant in certain pairs, but not all. Additionally, the result from a satisfaction survey demonstrated that the training method was perceived to be at the highest level of satisfaction. Nonetheless, participants' written comments indicate advantages and disadvantages of the training.
\end{abstract}

Keywords: proprioceptive method, English, training, Facebook, Thai

\section{Introduction}

In intelligible communication, listening and speaking skills are unavoidably intertwined. Listening is not only the most fundamental skill for communication (Mukminatun, 2009, Rivers \& Temperley, 1978) but also crucial for learning any other language skills (Vandergrift, 1999). However, listening can be a demanding skill for second language learners because it is spontaneous (Nunan, 2003; Lund, 1991). In fact, most learners of English as a foreign language (EFL) claimed that listening is the most difficult skill to acquire (Wilson, 2009). In addition to listening, pronunciation is also one of the essential aspects of efficient communication (Hismanoglu, 2006), as it is vital for speaking, which depicts the speaker's communicative competence (Morley, 1991). Learning to differentiate sounds and to pronounce them correctly is in the first stage of learning a language, either as a mother tongue or a foreign language (Hoff, 2014).

Speaking EFL with good pronunciation despite errors in grammar tends to result in commendation (Akter, 2007), whereas speaking with bad pronunciation but good grammar may cause amusement and embarrassment (Akter, 2007). Speaking profoundly depends on coherent pronunciation (Jenkins, 2004). Pronunciation can elicit socio-cultural judgments (Gelvanovsky, 2002) that activate influential attitudes on the speaker's identity (Jenkins, 2005). Additionally, learners with good pronunciation could develop other linguistic skills more rapidly than those with bad pronunciation (Fraser, 2000). Non-native speakers of English with unintelligible pronunciation are likely to be considered as inept or even illiterate.

Nonetheless, pronunciation of a foreign language is one of the most difficult aspects to acquire. Without the ability to listen and distinguish sound segments in words and sentences, EEL learners frequently encounter impediments of understanding English. Without the ability to efficiently understand English sounds, words and sentences, the learners are less likely to pronounce them effectively. Yet, classroom instruction was ineffective (Derwing \& Rossiter, 2002). Next, mispronunciation often occurred because EFL learners could not produce unfamiliar sounds (Brown, 1987). Furthermore, a conversation task did not aid their pronunciation (Osburne, 
2003). In addition, pronunciation was not included in learning materials (Habib, 2013).

Thailand's national curriculum of foreign language pedagogy stipulates that learners' ability to listen and segregate English sounds and understand the sound patterns is required. Although English has been required to be taught at school and university levels, most Thai people are very reluctant to speak English.

As Thai EFL learners have had difficulty of perceiving and pronouncing certain sounds of English, particularly those that do not exist in the Thai sound system, the current study aimed to investigate the effect of the Feedback Training Method used in listening and speaking practice by the Thai officials of local government administration on their auditory perceptions of English sounds that are commonly problematic to Thai EFL learners. The practice was principally exercised with the aid of Facebook.

\subsection{Problems of Sound Perception}

Recent studies have shown that some sound units (phonemes) are hard to perceive; for example, /f/ in both onset and coda positions (Kittredge \& Dell, 2016). In addition, discrimination of sound contrasts is also problematic; for instance, /f/ - /h/ in the onset position as in faa or haa (Fukuda, Rothermel, Juhasz, Nishida, \& Asano, 2010), /f/ - /s/ as in fail or sail and /b/ - /d/ as in bump or dump (Bowers, Kazanina \& Andermane, 2016), as well as /b/ $/ \mathrm{p} /$ as in $b a$ or $p a$ (Segal, Hejli-Assi \& Kishon-Rabin, 2016). Actually, lacking the ability to distinguish phonemes, segmental or suprasegmental, can lead to impaired reading capability; thus, training of phonemic cognizance is recommended (Mannel, Schaadt, Illner, Meer, \& Friederici, 2017).

\subsection{Pronunciation Problems by Thais Studying English}

There are not many published studies on English pronunciation by Thai learners in the databases. Nonetheless, all studies reviewed below showed that English learners whose first language is Thai are confronted with hindrances regarding pronunciation of the English sounds.

Concerning the English consonants pronounced by Thai students at a university level, Tantanit (2013) found that initial consonant sounds in English, which were problematic for Thai learners, were $/ \mathrm{v}, \theta, \mathrm{\partial}, \mathrm{z}, \mathrm{I}, \mathrm{l}, \int \mathrm{t} \mathrm{t} /$. Examples of these sounds could be illustrated as in van, thin, then, zoo, road, load, shoe, chin. Besides, the learners hardly pronounce certain final consonant sounds correctly. These were /f, v, $\theta, \partial, \mathrm{s}, \mathrm{z}, 1, \int, \mathrm{t} \mathrm{f} /$ as in safe, five, bath, bathe, bus, close, ball, wash, watch. The source of these difficulties lied in the interference of the first language and simplification.

Similarly, Kanokpermpoon (2004) reported that Thai students ineffectually pronounced word-initial voiced fricatives: /v, $\theta, \partial, \mathrm{z}, \int, 3 /$ and word-final fricatives: either voiceless $/ \mathrm{f}, \theta, \mathrm{s}, \int /$ or voiced /v, $\partial, \mathrm{z}, \mathrm{z} /$. In fact, they confront with difficulties of pronouncing English consonants that did not have Thai counterparts.

According to Wei \& Zhou (2002), Thai EFL learners challenged with pronunciation difficulties as follows. They often add a vowel between the first and the second consonants of consonant clusters as in street and spade. The $/ \mathrm{r} /$ sound as in strawberry and grass is pronounced with the $/ 1 /$. The $/ \theta /$ sound as in think and feather is replaced with $/ \mathrm{z} /$ or $/ \mathrm{s} /$, while $/ \mathrm{v} /$ as in five end Steve is substituted with $/ \mathrm{f} /$. The $/ \mathrm{z} /$ as in bus $\underline{s}$ and vas e is pronounced with $/ \mathrm{s} /$, and the $/ 3 /$ sound in television and pleasure is generally pronounced as $/ \mathrm{s} /$.

In addition, Tuaycharoen (1990) found challenging English sounds for Thais, for example, plosives like /p, t, k/ in soap, lot, sack were pronounced without aspiration, which made them hard to comprehend. Also, the sound /g/ as in google, which does not exist in the Thai language, was replaced with $/ \mathrm{k} /$. The syllabic $/ \mathrm{m}, \mathrm{n}, \mathrm{g} /$ at the end of a word as in rhythm, sudden, singing made it difficult for Thais to pronounce. Challenging fricatives that do not exist in the Thai sound system included $/ \Theta, \delta, \int, 3, v, z /$; however, Thais could pronounce /f, s/ in the initial position of a syllable but not at the end of a word. Additionally, Thais had trouble pronouncing particular sounds in the word-final position such as affricates $/ \mathrm{t} \int \mathrm{d} 3 /$ as in watch, judge and the lateral sound /1/ as in ball, call.

As seen in the aforementioned studies, English consonant sounds that are not compatible with Thai consonant sounds are problematic to Thai people. In fact, to process good pronunciation, good perceptions of sounds are obligatory. However, before speaking, a language learner needs to listen. Thus, practical methods of pronunciation teaching or training should be provided, especially for solving these pronunciation dilemmas. Hitherto, research on how to teach segmentation of English sound contrasts by Thais has been inadequate. Furthermore, the Proprioceptive Method or Feedback Training which has been used for language production and perception is claimed to be effective for learning pronunciation, listening, speaking, reading and grammar in real time (Lundquist, 2012). Yet, research on the effectiveness of this method is very limited. Consequently, this method is used and evaluated in this study regarding the training of English pronunciation and listening for differentiation of problematic English sound units. Last of all, digital technologies, online information and communication, as well as active learning tend to be indispensible in $21^{\text {st }}$ century pedagogies (Beetham \& 
Sharpe, 2013). Accordingly, Facebook, together with its features such as secret groups and chat rooms, is adopted as a tool for online autonomous (self-directed) learning using the Proprioceptive Method, coach's suggestions, and learners' comments regarding the training course in this study.

\subsection{Proprioceptive or Feedback Training Method}

The Proprioceptive Method or Feedback Training Method is a teaching method that focuses on the integrated training of the language and the brain in which the learner's perception, memory, listening and speaking are processing in real time. According to Lundquist (2012), human speech deals with the central nervous system, related speech organs and hearing. In real-time processing, while the brain is receiving the heard information, the mouth is producing speech, breathing and feeding back the pronunciation and grammar to the brain. In learning English as a foreign language, practice of listening and speaking is more crucial than the traditional method that focuses on grammar, reading and writing. This is because the learner can learn or even acquire grammar via listening and speaking, which simultaneously interact with the proprioceptive sense and the neurological function. In actual fact, reading aloud results in a better memorization of sentence elements than reading silently as the former allows the mouth to feed back the information to the brain whereas the latter primarily works with memory (Lundquist, 2012). In addition, four principles of speaking practice should be emphasized: speak out loud, think in the target language, speak as much as possible and use the Feedback Training Method. The Feedback Training Method includes several techniques, four of which are described as follows. First, the learner should speak merely the language with correct pronunciation and grammar. Speaking incorrectly is like setting the mouth, the brain and the hearing for the inaccurate pronunciation and grammar, instigating hindrances to learning the precise ones. Next, during the speaking practice, the learner should be assured that the pronunciation is right. Also, while reading out loud, the learner should avoid looking at the written words but try to memorize them, instead. Additionally, recordings of the spoken language such as conversations, news and radio broadcasting can be used for practice. Importantly, the learner must apprehend the pronunciation, words and grammar of the speech excerpt used for speaking practice.

As previously mentioned, listening and pronunciation have long been problematic to Thai people learning English and the Feedback Training Method has been claimed to be efficient for listening and pronunciation; therefore, this study aimed to explore the effects of the Feedback Training Method on the listening and pronunciation skills of Thai local government officials. It has the following research questions:

1) Was there any significant difference between the minimal-pair listening test scores that the Thai local government officials made before and after using the Proprioceptive Method in learning English via Facebook?

2) What reflections did the trainees perceive after employing the Proprioceptive Method in learning English via Facebook?

\section{Method}

\subsection{Participants}

The participants were randomly recruited via their organization heads who received a letter of request for research assistance from the director of the second author's affiliation. They filled in the application form with their Facebook account identification and signed a consent form. In the beginning of this study, 37 government officials from 10 local sub-district administrative organizations in Muang District, Kamphaengphet Province, which is in the lower north of Thailand, signed in enthusiastically. They were adults at the age between 21 and 52 , and each of them received a bachelor's degree. They all participated in the first training class; nonetheless, only 30 participants completed the training course.

\subsection{Research Instruments}

There were two research instruments. One was a packet of 15 conversation recordings chosen from englishspeak.com. The other was a written pretest/posttest of sound contrast in English, adopted from British Council's sound contrast exercise. The test included 59 minimal pairs: 10 for $/ \mathrm{r} / \mathrm{vs}$. /1/ e.g., road vs. load, 10 for consonant cluster e.g., glass vs. grass, 9 for /v/ vs. /w/ e.g., veal vs. wheel, 10 for /t/ vs. / / / e.g., tin vs. thin, 10 for $/ \mathrm{f} / \mathrm{vs}$. /t $\mathrm{t} /$ e.g., shop vs. chop, and 10 for /s/ vs. /z/ e.g., sue vs. zoo. The learners were asked to listen to the recording and circle the word they heard.

\subsection{Data Collection}

The data in this study were gathered in an English training course. It was seventeen days long. It was divided into three phases: a pretest implementation followed by face-to-face training, remote training via Facebook, and a posttest conduction and course evaluation. The face-to-face training was implemented for the first two days. In 
fact, the participants signed in and completed the listening pretest before attending the training of English listening and speaking in the word level and sentence level, respectively. Exercises and activities such as games, songs and role plays were utilized. Two trainers acted more like facilitators. After the face-to-face training, the participants distantly studied fourteen English conversations spoken by two native speakers of English, which were selected from englishspeak.com. The link of one conversation was sent to their Facebook group every day. The participants were given instructions of how to study the lessons, sentences, words, and pronunciation in their first language. Then, they were required to mimic the speech they heard and record their speaking. Subsequently, they should listen to their own speaking and compare it to the native speakers'. If they found something wrong, they need to start it over. Speaking without looking at the script was recommended, but it was not required. Once they were satisfied with their speaking, they should submit their recording in the form of mp.4 file to the Facebook group. If they had any question or comment, they could post it on a group wall or on a group chat room. They were allowed to study at their own convenient time, pace and place. All they need was an electronic device such as a phone or I-Pad or computer with Facebook and the Internet.

Every day a teaching specialist would check the recordings and gave feedback regarding the pronunciation individually via Facebook comments. The participants were requested to read the feedback and tried to avoid the same problem in the following assignment. On the last day of the training, the participants and the trainers met for the posttest and course evaluation. In short, the data was collected using the Feedback Training Method or Proprioceptive Method, a pronunciation training method of individual practice and one-on-one corrective feedback. The trainees were requested to leave reflections and comments regarding the training's impacts on their pronunciation.

\section{Results}

The results of this study are divided into two parts: the listening one and the pronunciation one.

\subsection{Results from Listening Tests}

In order to demonstrate the difference between the pretest scores and the posttest scores, which the participants earned before and after the feedback training, a comparison of the pretest-posttest raw scores is demonstrated in Table 1.

Table 1. Comparison of the participants' pretest scores and posttest scores

\begin{tabular}{|c|c|c|c|c|c|c|c|c|c|c|c|c|c|c|}
\hline \multirow{3}{*}{ No } & \multicolumn{2}{|c|}{ All sounds } & \multicolumn{2}{|c|}{ /r/ vs /l/ } & \multicolumn{2}{|c|}{$\mathrm{C} / \mathrm{r} /$ vs $\mathrm{C} / \mathrm{l} /$} & \multicolumn{2}{|c|}{$/ \mathrm{v} / \mathrm{vs} / \mathrm{w} /$} & \multicolumn{2}{|c|}{$/ \mathrm{t} / \mathrm{vs} / \theta /$} & \multicolumn{2}{|c|}{$/ \int /$ vs $/ \mathrm{t} \int /$} & \multicolumn{2}{|c|}{$/ \mathrm{s} / \mathrm{vs} / \mathrm{z} /$} \\
\hline & Pre & Post & Pre & Post & Pre & Post & Pre & Post & Pre & Post & Pre & Post & Pre & Post \\
\hline & 59 & 59 & 10 & 10 & 9 & 9 & 10 & 10 & 10 & 10 & 10 & 10 & 10 & 10 \\
\hline 1 & 39 & 38 & 5 & 5 & 6 & 3 & 6 & 7 & 5 & 7 & 4 & 3 & 5 & 6 \\
\hline 2 & 38 & 43 & 0 & 6 & 0 & 4 & 1 & 6 & 0 & 4 & 4 & 5 & 3 & 7 \\
\hline 3 & 35 & 36 & 9 & 10 & 5 & 8 & 7 & 1 & 7 & 8 & 5 & 4 & 6 & 7 \\
\hline 4 & 35 & 34 & 4 & 5 & 5 & 5 & 4 & 7 & 5 & 9 & 5 & 1 & 4 & 6 \\
\hline 5 & 33 & 33 & 5 & 7 & 3 & 4 & 5 & 7 & 4 & 5 & 4 & 6 & 5 & 5 \\
\hline 6 & 33 & 43 & 5 & 9 & 3 & 6 & 4 & 7 & 7 & 6 & 5 & 7 & 6 & 6 \\
\hline 7 & 32 & 27 & 5 & 5 & 4 & 5 & 5 & 5 & 7 & 8 & 3 & 2 & 5 & 3 \\
\hline 8 & 32 & 32 & 4 & 3 & 5 & 6 & 4 & 7 & 5 & 9 & 5 & 6 & 6 & 9 \\
\hline 9 & 31 & 31 & 5 & 8 & 4 & 6 & 4 & 4 & 2 & 3 & 2 & 4 & 4 & 6 \\
\hline 10 & 31 & 25 & 7 & 6 & 2 & 4 & 3 & 6 & 4 & 4 & 4 & 7 & 5 & 6 \\
\hline 11 & 31 & 33 & 8 & 6 & 4 & 5 & 6 & 4 & 4 & 9 & 4 & 4 & 7 & 5 \\
\hline 12 & 30 & 41 & 5 & 6 & 6 & 5 & 6 & 7 & 7 & 9 & 4 & 6 & 7 & 3 \\
\hline 13 & 30 & 34 & 4 & 6 & 3 & 4 & 4 & 6 & 5 & 6 & 2 & 5 & 4 & 5 \\
\hline 14 & 30 & 30 & 6 & 8 & 5 & 7 & 4 & 7 & 5 & 3 & 6 & 4 & 4 & 5 \\
\hline 15 & 30 & 35 & 3 & 4 & 7 & 4 & 3 & 8 & 4 & 8 & 5 & 4 & 2 & 5 \\
\hline
\end{tabular}




\begin{tabular}{lllllllllllllll}
\hline 16 & 29 & 28 & 8 & 10 & 4 & 6 & 9 & 9 & 8 & 9 & 4 & 2 & 5 & 7 \\
\hline 17 & 29 & 40 & 4 & 6 & 5 & 1 & 5 & 7 & 3 & 8 & 6 & 5 & 6 & 5 \\
\hline 18 & 29 & 32 & 4 & 6 & 5 & 5 & 4 & 3 & 4 & 9 & 7 & 8 & 1 & 6 \\
\hline 19 & 28 & 29 & 5 & 8 & 3 & 5 & 4 & 7 & 2 & 6 & 2 & 4 & 3 & 6 \\
\hline 20 & 27 & 33 & 6 & 4 & 5 & 4 & 4 & 3 & 4 & 7 & 4 & 6 & 5 & 5 \\
\hline 21 & 27 & 38 & 7 & 5 & 7 & 5 & 4 & 4 & 5 & 4 & 4 & 3 & 5 & 6 \\
\hline 22 & 26 & 34 & 2 & 6 & 0 & 5 & 3 & 4 & 1 & 7 & 4 & 4 & 4 & 7
\end{tabular}

Table 1. Comparison of the participants' pretest scores and posttest scores (continued)

\begin{tabular}{|c|c|c|c|c|c|c|c|c|c|c|c|c|c|c|}
\hline \multirow{3}{*}{ No } & \multicolumn{2}{|c|}{ All sounds } & \multicolumn{2}{|c|}{ /r/ vs /1/ } & \multicolumn{2}{|c|}{$\mathrm{C} / \mathrm{r} /$ vs $\mathrm{C} / \mathrm{l} /$} & \multicolumn{2}{|c|}{$/ \mathrm{v} / \mathrm{vs} / \mathrm{w} /$} & \multicolumn{2}{|c|}{$/ \mathrm{t} / \mathrm{vs} / \theta /$} & \multicolumn{2}{|c|}{$/ \mathrm{J} / \mathrm{vs} / \mathrm{t} \mathrm{f} /$} & \multicolumn{2}{|c|}{ /s/ vs /z/ } \\
\hline & Pre & Post & Pre & Post & Pre & Post & Pre & Post & Pre & Post & Pre & Post & Pre & Post \\
\hline & 59 & 59 & 10 & 10 & 9 & 9 & 10 & 10 & 10 & 10 & 10 & 10 & 10 & 10 \\
\hline 23 & 25 & 33 & 6 & 6 & 5 & 5 & 7 & 5 & 4 & 3 & 4 & 5 & 4 & 6 \\
\hline 24 & 25 & 37 & 5 & 7 & 5 & 8 & 6 & 4 & 3 & 7 & 4 & 6 & 4 & 6 \\
\hline 25 & 24 & 33 & 8 & 5 & 4 & 6 & 6 & 8 & 5 & 5 & 6 & 6 & 6 & 4 \\
\hline 26 & 22 & 32 & 10 & 10 & 5 & 6 & 4 & 6 & 6 & 8 & 2 & 7 & 6 & 6 \\
\hline 27 & 21 & 31 & 6 & 7 & 5 & 6 & 5 & 8 & 4 & 4 & 4 & 4 & 6 & 6 \\
\hline 28 & 19 & 36 & 7 & 5 & 5 & 4 & 7 & 5 & 5 & 4 & 5 & 6 & 3 & 8 \\
\hline 29 & 14 & 33 & 5 & 5 & 6 & 4 & 6 & 6 & 6 & 4 & 4 & 4 & 4 & 2 \\
\hline 30 & 8 & 32 & 5 & 6 & 7 & 7 & 6 & 7 & 4 & 2 & 5 & 5 & 4 & 6 \\
\hline
\end{tabular}

For clearer pictures of the comparisons between the pretest and posttest scores, the results of the overall achievement scores from the entire listening test of phonemes or sound units in minimal pairs and those from each pair of phonemes can be illustrated in graphs as follows.

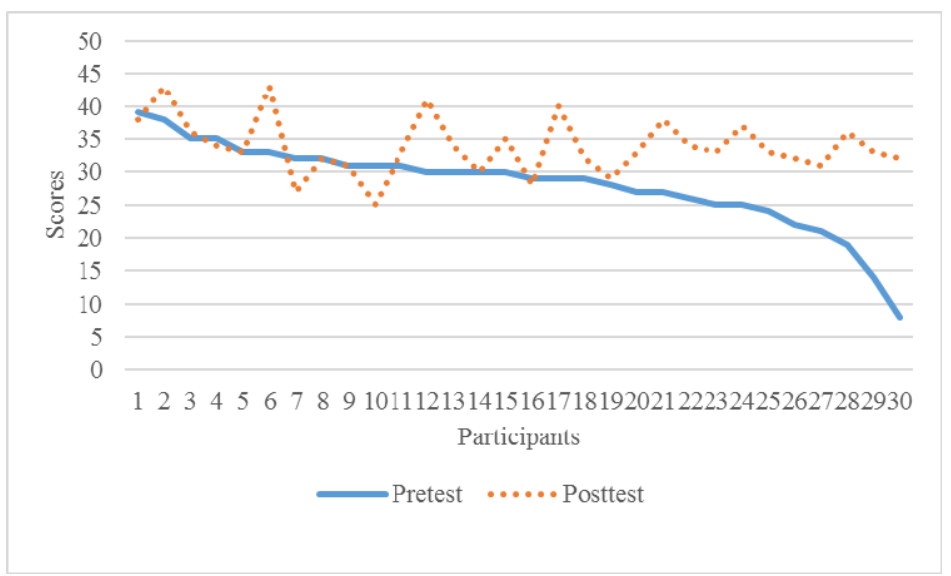

Figure 1. The pretest vs posttest scores obtained from the minimal-pair listening test 


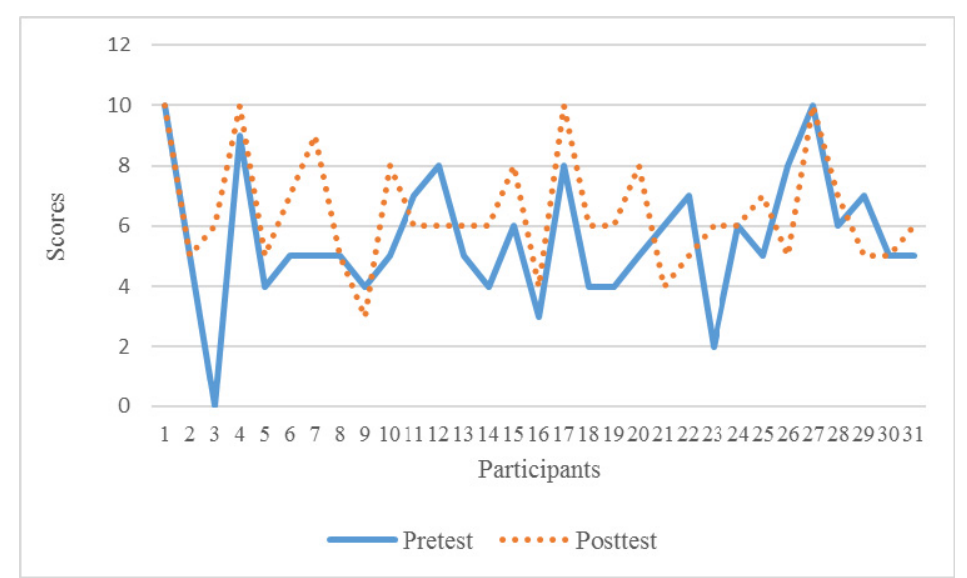

Figure 2. The pretest vs. posttest scores of listening perceptions of /r/vs. /1/ in minimal pairs

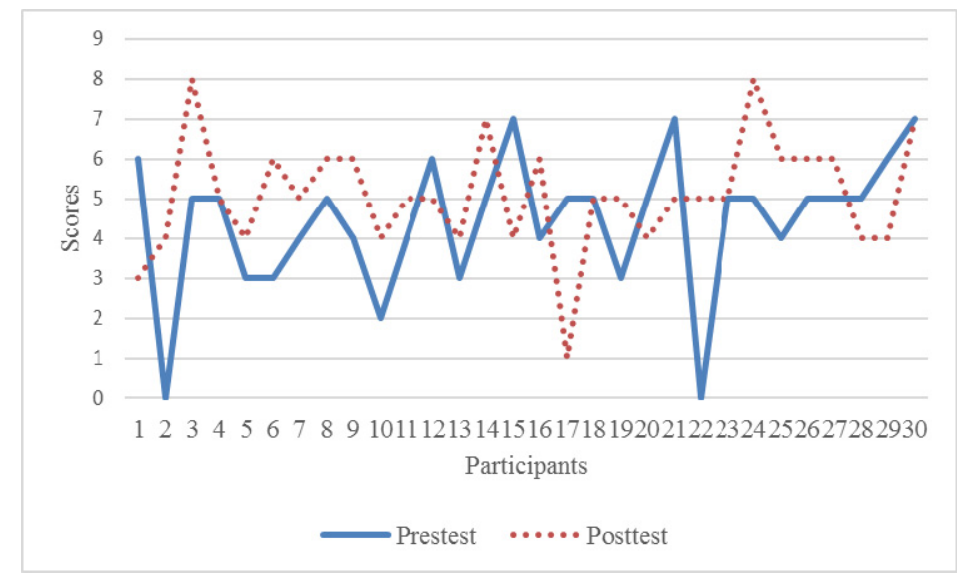

Figure 3. The pretest vs. posttest scores of listening perceptions of $\mathrm{C} / \mathrm{r} / \mathrm{vs}$. $\mathrm{C} / \mathrm{l} / \mathrm{in}$ minimal pairs

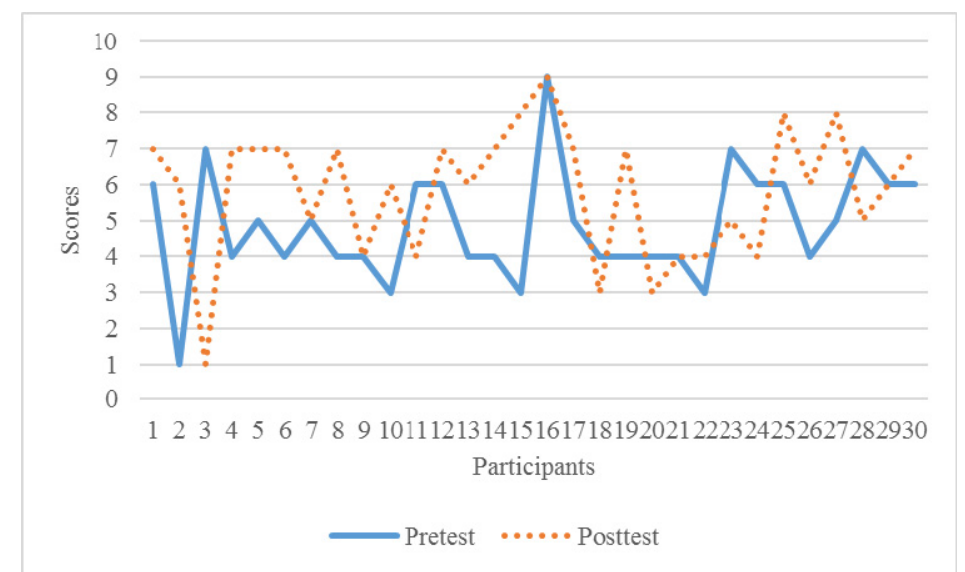

Figure 4. The pretest vs. posttest scores of listening perceptions of $/ \mathrm{v} / \mathrm{vs}$. $/ \mathrm{w} /$ in minimal pairs 


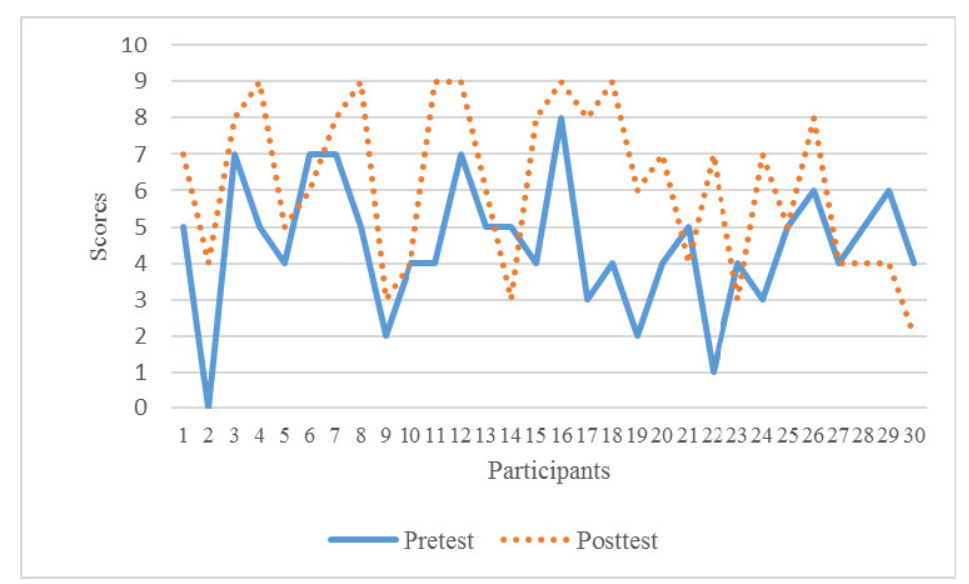

Figure 5. The pretest vs. posttest scores of listening perceptions of /t/ vs. /e/ in minimal pairs

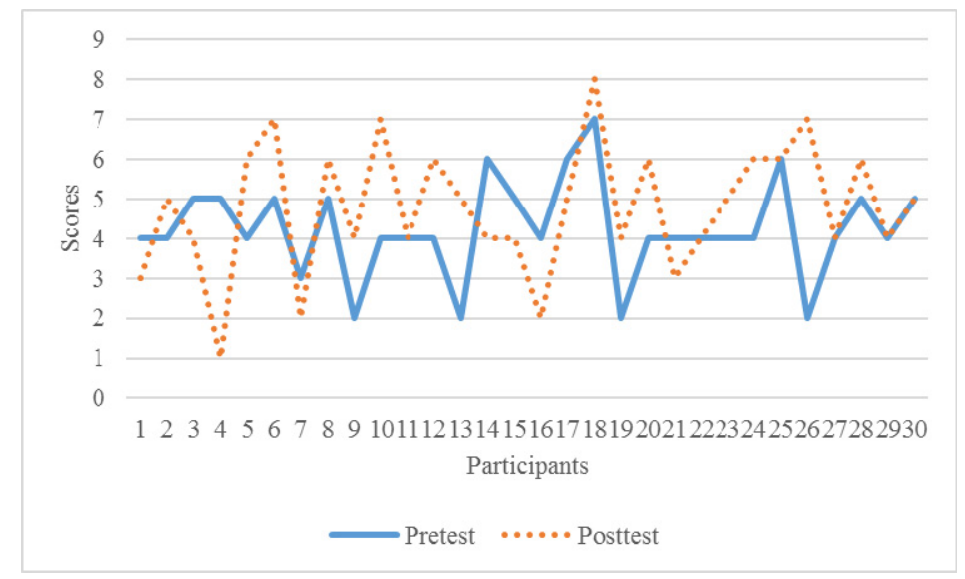

Figure 6. The pretest vs. posttest scores of listening perceptions of $/ \mathrm{J} / \mathrm{vs}$. $/ \mathrm{t} / \mathrm{in}$ minimal pairs

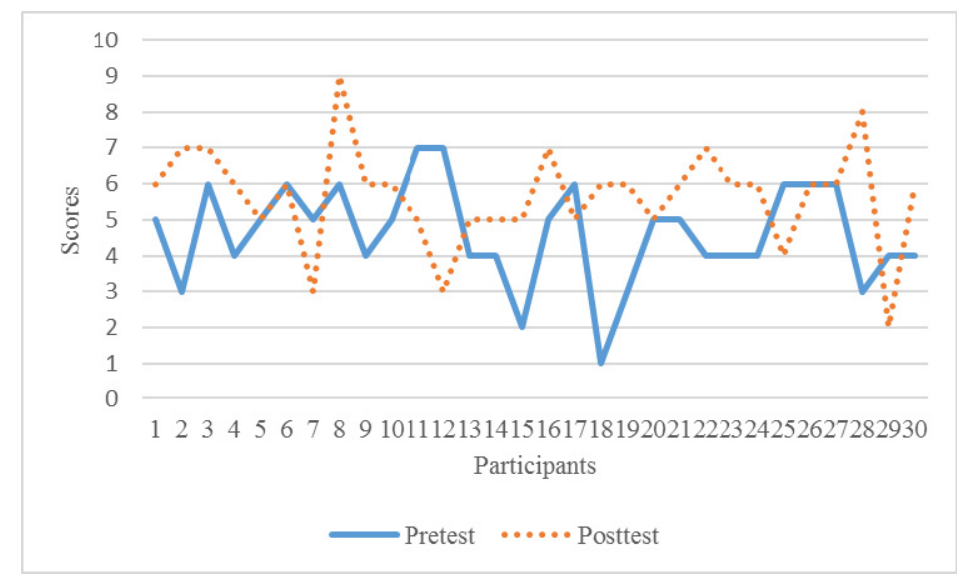

Figure 7. The pretest vs. posttest scores of listening perception of /s/vs. /z/ in minimal pairs

To decide whether the differences were statistically significant, paired samples t-test statistics were used. The statistic results are shown in Table 2. 
Table 2. Statistic results regarding the differences between the participants' posttest scores and pretest scores

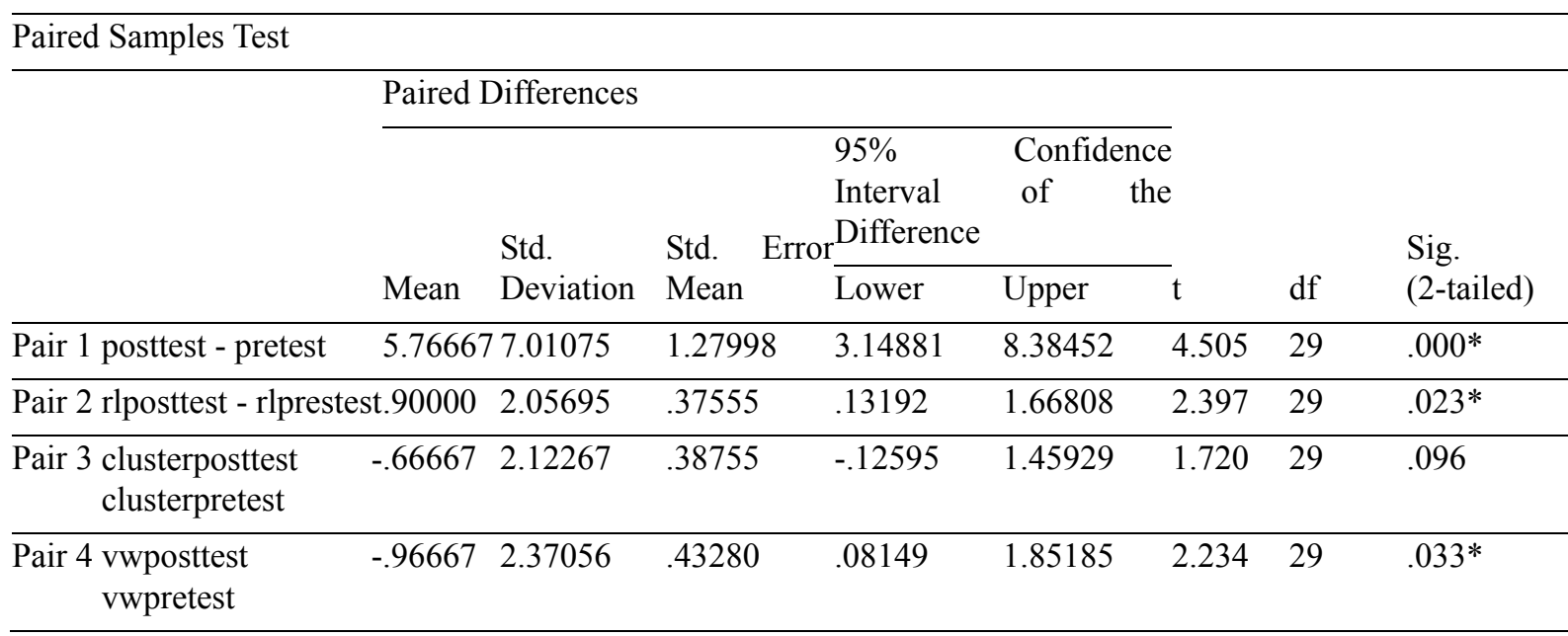

Table 2. Statistic results regarding the differences between the participants' posttest scores and pretest scores (continued)

Paired Samples Test

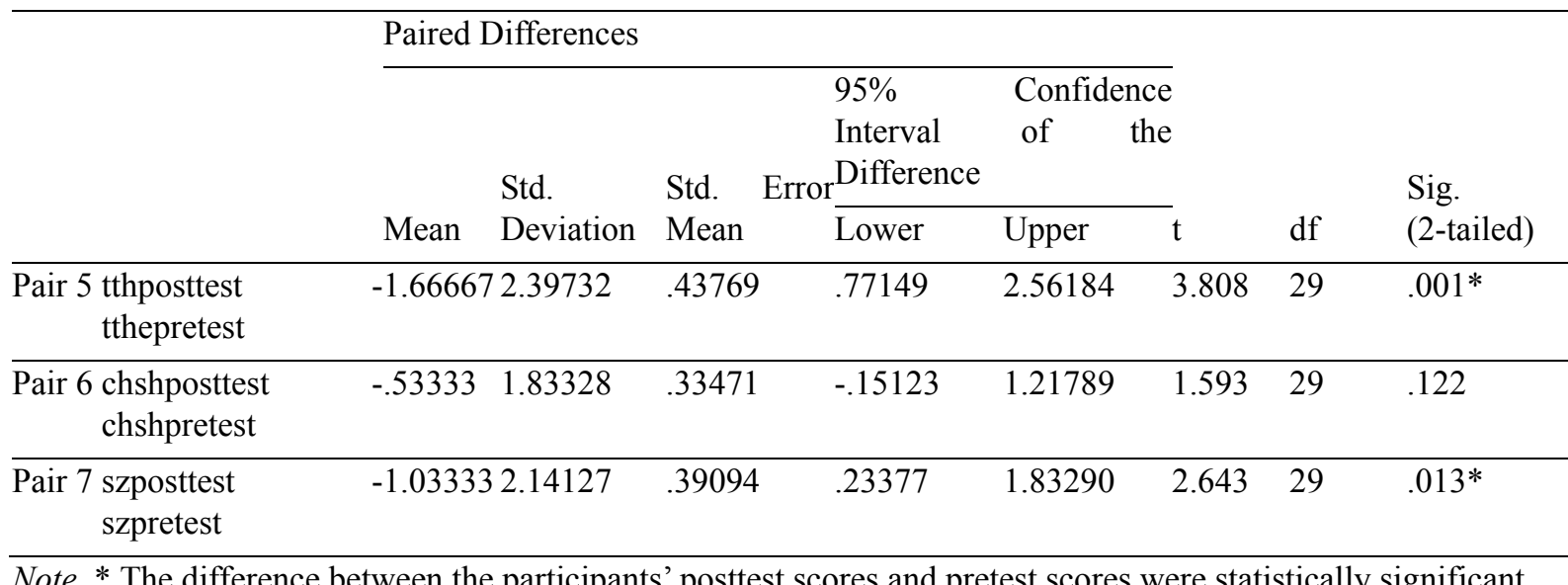

Statistically, the t-test statistic results in Table 2 showed that there was a significant difference between the learners' overall pretest scores and posttest scores at the alpha level of $.001(t=4.505, \mathrm{p}<.001)$. This indicates that the feedback training method was strongly effective for listening for phoneme segregation. For minimal pairs of the sound contrasts, the results showed statistic differences between the trainees' posttest scores and pretest scores in four parts: 1$) / \mathrm{r} / \mathrm{vs} . / 1 /(t=2.397, \mathrm{p}<.05), 2) / \mathrm{v} / \mathrm{vs} . / \mathrm{w} /(t=2.234, \mathrm{p}<.05), 3) / \mathrm{t} / \mathrm{vs} . / \theta /(t=$ $3.808, \mathrm{p} \leq .001)$, and 4$) / \mathrm{s} / \mathrm{vs} . / \mathrm{z} /(t=2.643, \mathrm{p}<.05)$. The results indicate that the Feedback Training Method employed in this study was likely to be highly effective for empowering the trainees' auditory perceptions ability regarding English sound contrast segregation. However, for certain sound contrasts, that is, $\mathrm{C} / \mathrm{r} / \mathrm{vs}$. C/l/ (consonant clusters followed by either $/ \mathrm{r} /$ or $/ \mathrm{l} /$ ) and $/ \mathrm{f} / \mathrm{vs}$. $/ \mathrm{t} / \mathrm{f}$, the trainees' posttest scores were not statistically higher than their pretest ones. In other words, to differentiate $\mathrm{C} / \mathrm{r} /$ from $\mathrm{C} / \mathrm{l} / \mathrm{\text {and }} / \mathrm{g} / \mathrm{from} / \mathrm{t} \mathrm{J} /$ are tougher for the participants than any other minimal pairs of the phonemes (sound units) in question.

\subsection{Results from the Trainees' Reflections of the Training}

Apart from the statistical results, a survey of the training course satisfaction was given to all participants on the last day of the course. The result indicated that the participants were highly satisfied with the course with the mean value of 4.58 out of 5.0. Additionally, the trainees' reflections of their pronunciation improvement were illustrated in their written comments in the chat room. The language used was Thai, but in this article it was translated into English. The comments were analyzed and grouped according to the content similarity. These qualitative results showed that the trainees $(\mathrm{T})$ felt that their overall pronunciation improved individually. Not 
only did the training facilitate speaking skill, but it also supported listening skill. The coach's comments and suggestions were helpful for pronunciation development.

Besides, they thought that their pronunciation was more accurate, as they posted:

"It helped me practice pronunciation (that is) closer to a native speaker." - T2

"I could speak more correctly and more clearly." - T5

"It helped me to pronounce more correctly and use sentence stress better." - T3

"It helped me improve my speaking skill." - T6

"I could speak more fluently." - T7

"For pronunciation, because I listened to native speakers' accents, I could pronounce

(English) more correctly." - T8

"I learned English and (English) pronunciation." - T10

Nevertheless, a trainee reported her difficulty of pronouncing English though her pronunciation improvement after the training occurred, as follows.

"However, sometimes I didn't really understand how to pronounce (it). I tried and it was still the same (incorrect). Sometimes it was my habit. I practiced many times. When it was the right time (to record my pronunciation), it (my pronunciation) was always the same (wrong). I needed a lot of practice... However, personally, I knew how to better pronounce English. Yet, I could not pronounce it all correctly." - T9

In addition to the advantage of pronunciation improvement, the training tended to benefit not only speaking skill but also listening skill, as the trainees stipulated:

"It's good. I can practice listening and speaking in unison"- T1.

"My listening skill was bad. I had to listen many times. Finally, I used to it." - T4

"For listening, it helped me get used to the accents. When listening to them more often, I could comprehend what the speaker said or meant."- T5

"(The training) helped pronunciation a lot. Also, it helped listening skill as well. It helped a lot. I like it a lot." T9

Furthermore, in the remote training, a coach offered comments and suggestions to each recording of each trainee every day. This type of feedback was considered helpful for pronunciation enhancements. Below were trainees' comments on the coach's feedback.

"When I got comments, I knew the mistakes that I needed to correct." - T1

“....and when (I made) mistakes, I got suggestions. I could use them to practice (again). Now I could speak more naturally and remember how to speak the sentences." - T6

"(It) helped me realize my weaknesses and how to improve (them). (For) some words, I thought they were pronounced like that continually, and they were wrong continually. Ha ha." - T7

“....and for the coach's feedback, it identified my mistakes of incorrect pronunciation such as words ending with $-\mathrm{s}$, -sts, -ed or the pronunciation of words with the /v/ sound." - T8

Finally, reflections from the trainees indicated that the overall training course was exceptional and expedient, as shown in the following statements.

"I like the way we study. It's convenient. I can study anytime." - T11

"I like the teaching part. Thank you for this training. I like it a lot."- T12

"I learned English and (English) pronunciation. The training is different from any other trainings. I joined a training for a day or two (and) it was complete. But in this training, I had to practice every day and the coach gives me comments, resulting in self-development and self-improvement. It was good. I like it." - T10

"The teaching (training) method was good, up to date, and time-saving as we didn't have to sit in class. However, sometimes I didn't really understand how to pronounce (it). I tried and it was still the same (incorrect). Sometimes it was my habit. I practiced many times. When it was the right time (to record my pronunciation), it (my pronunciation) was always the same (wrong). I needed a lot of practice. It was good that the model conversations were given, and I could choose to hear certain words. This (the distant training) was very good... However, personally, I knew how to better pronounce English. Yet, I could not pronounce it all correctly. In 
general, it (the course) was very good. It was not boring and I could study anywhere, anytime. Thank you." - T9

Nevertheless, there were some drawbacks of the course according to the participants' written opinions left on the chat rooms. They included the Internet speed and the device used for listening and recording.

"The hindrance was the instrument and the Internet. The Internet was slow resulting in late submissions of assignments. Certain words could not be played on the phone. So I didn't know how to pronounce them correctly."'- T13

"The Internet (I used) was very slow so I changed the Wi-Fi program by paying more, from 199 to 499. (Then) it worked well." - T14

"It was bad that (the conversations) could not play on (my) phone. (I) needed to use the PC only." - T15

"I didn't have time. (My) organization was not serious (about this training)." - T16

\section{Discussion}

The results from this study showed similarities with and differences from previous studies. Specifically, the overall statistic result which indicated that the Feedback Training Method was significantly helpful for listening for phoneme segregation $(t=4.505, \mathrm{p}<.001)$ was in concord with the suggestion made by Mannel, Schaadt, Illner, Meer \& Friederici (2017) in that training of phonological awareness can enhance the auditory perception ability to differentiate phonemes. Listening to the self-pronunciation and making sure that it was right helped the trainees to identify the English phonemes in a spoken word more accurately.

In addition, the above results also indicated that the sounds that were hard to produce were also hard to perceive. Accordingly, the results offered a further insight to the findings of Tuaycharoen (1990), Wei and Zhou (2002) and Kanokpermpoon (2004), who found that producing / $\Theta, \varnothing, \mathrm{v}, \mathrm{Z} /$ was problematic to Thais. In addition, this study found that $/ \mathrm{t} \int, \int,(\mathrm{C}) \mathrm{l} /$ were harder to perceive than such problematic sounds. Also, the results contradicted to the influence of L1 as a cause of either mispronunciation or mishearing. The phonemes $/ \Theta, \succ, v, z /$, which do not exist in the Thai sound system, could be heard correctly by the Thai trainers of English in this study, while the phonemes / $\mathrm{t}$, (C)l, (C)r/ that do exist in the Thai system were judged erroneously. Hence, the study suggested that these sound units be specially trained to Thai learners of English.

In a big picture, the speaking ability assessments showed that the trainees who consistently practiced speaking the dialogues given every day tended to pronounce the problematic sounds much better due to their self-corrections after reading their coach's written feedback given in comments below their posts. Nonetheless, individual difference played a crucial role in pronunciation as some persistently encountered problematic pronunciation of certain sounds while others did not. In effect, it was the trainees' constant exposure to English and their intentions to be more fluent in English that counted for their pronunciation improvement.

Regarding the participants' perspectives of the Feedback Training Method, it can be inferred that the training course that included face-to-face training with distant training via the Feedback Training Method or the Proprioceptive Method was effective for listening and speaking skills. It was viewed as convenient, time-saving, and modern. It also allowed the participants to learn at their convenient place and time. On the other hand, the online lessons, the Internet, and the apparatus used were essential in order to make the learning efficient. Furthermore, serious support and cooperation from the participants, as well as their organizations, were crucial. Following the instructions and timeline of learning might help them learn more effectually.

In conclusion, the current study shows that training a foreign language via Facebook by using the Proprioceptive or Feedback Training Method can raise phoneme awareness for the reason that the trainees can discriminate sound contrasts efficiently. Additionally, it assists learning pronunciation and speaking skills, together with the use of Information Technology. Hence, it is recommended for blended learning environment, distant learning, and remote training. Researchers can also implement research on the advantages of this method on learning other language skills. By the same token, it is suggested that EFL learners practice listening and speaking via this method on their own.

The outcomes from this study should also benefit EFL teachers and trainers because this listening and speaking practice via Facebook can reduce their lecture time while they can provide comments and feedback to individual learners, interact more with learners individually or in group, and keep tracks of their learning. The techniques of listening and speaking practice via Facebook could also be used as a guideline to all EFL learners who are longing to learn English according to their own pace, time and place.

\section{Acknowledgments}

The authors would like to especially express deep appreciation to Kamphaengphet Rajabhat University, who 
kindly sponsored this research, and the directors of local government offices in the municipality of Kamphaengphet, who allowed employees to participate in this project.

\section{References}

Akter, Z. (2007). Teaching Pronunciation: Does it matter? MET, 16(3), 36-38.

Beetham H., \& Sharpe R. (2013). An Introduction to Rethinking Pedagogy. In H. Beetham \& R. Sharpe (Eds.) Rethinking Pedagogy. ( $2^{\text {nd }}$ ed.). NY, USA: Routledge.

Bowers, J. S., Kazanina, N., \& Andermene, N. (2016). Spoken word identification involves accessing position invariant phoneme representations. Journal of Memory and Language, 87, 71-83. https://doi.org/10.1016/j.jml.2015.11.002

Brown, H. D. (1987). Principles of language learning and teaching ( $2^{\text {nd }}$ ed.). Englewood Cliffs, NJ: Prentice-Hall.

Derwing, T. M., Munro, M. J., \& Rossiter, M. J. (2002). Teaching native speakers to listen to foreign accented speech. Journal of Multilingual and Multicultural Development, 23, 245-259. https://doi.org/10.1080/01434630208666468

Fraser, H. (2000). Coordinating Improvements in Pronunciation Teaching for Adult learners of English as a Second Language. Canberra: DETYA.

Fukuda, M., Fothernel, R., Juhasz, C., Nishida, M., Sood, S., \& Asano, E. (2010). Cortical gamma-oscillations modulated by listening and overt repetition of phonemes. NeuroImage, 49, 2735-2745. https://doi.org/10.1016/j.neuroimage.2009.10.047

Gelvanovsky, G. V. (2002). Effective pronunciation teaching: principles, factors, and teachability. In P.V. Sysoyev (Ed.). Identity, Culture and Language Teaching. USA: CREEES

Habib, R. B. (2013). (Un) Intelligibility in EIL Pronunciation: An Analysis. Journal of Humanities and Social Science, 14(4), 21-26.

Hismanoglu, M., \& Hismanoglu, S. (2011). Internet-based Pronunciation Teaching: An innovative route toward rehabilitating Turkish EFL learners' articulation problems. European Journal of Educational Studies, 3(1), 23-36.

Hismanoglu, M. (2006). Current perspectives on pronunciation learning and teaching, Journal of Language and Linguistic Studies, 2(1), 101-110.

Hoff, E. (2014). Language development. Belmont, CA: Wadsworth Cengage Learning.

Jenkins, J. (2004). Research in teaching pronunciation and intonation. Annual Review of Applied Linguistics, 24 , 109-125. https://doi.org/10.1017/s0267190504000054

Kanokpermpoon, M. (2004). English fricatives: A problematic area of Thai students pronunciation. Cultural Approach, 4(7), 61-76.

Kittredge, A. K., \& Dell, G. S. (2016). Learning to speak by listening: Transfer of phonotactics from perception to production. Journal of Memory and Language, 89, 8-22. https://doi.org/10.1016/j.jml.2015.08.001

Lund, R. J. (1991). A comparison of second language listening and reading comprehension. The Modern Language Journal, 75, 196-204. https://doi.org/10.1111/j.1540-4781.1991.tb05350.x

Mannel, C., Schaadt, G., Illner, F. K., Meer, E., \& Friederici. (2017). Phonological abilities in literacy-impaired children: Brain potentials reveal deficient phoneme discrimination, but intact prosodic processing. Developmental Cognitive Neuroscience, 23, 14-15. https://doi.org/10.1016/j.den.2016.11.007

Morley, J. (1991). The Pronunciation Component to the Speakers of Other Languages, TESOL Quarterly, 25, 481-520. https://doi.org/10.2307/3586981

Mukminatun, S. (2009). Empowering the students through listening diaries to motivate them to improve their listening ability. Jurnal Pendidikan Bahasa Dan Seni, 5, 87-96.

Nunan, D. (2003). Practical English Language Teaching. New York: McGraw-Hill/Contemporary.

Osburne, A. G. (2003). Pronunciation strategies of advanced ESOL learners. IRAL., 41, 131-143. https://doi.org/10.1515/iral.2003.005

Riswanto, \& Haryanto, E. (2012). Improving Students' Pronunciation through Communicative Drilling Technique at Senior High School (SMA) 07 South Bengkulu, Indonesia. International Journal of 
Humanities and Social Science, 2(21).

Rivers, W. M., \& Temperley, M. S. (1978). A Practical Guide to the Teaching of English as a Second Foreign Language. Oxford University Press, New York.

Rojanacheewinsupond, P., Sayankena, P., \& Watkhaolarm, P. (2009). The use of Cooperative Task-based Learning in Improving Students' English Pronunciation. Rajabhat Maha Sarakham University Journal; RMU.J, 3(2).

Segal, O., Hejli-Assi, S., \& Kishon-Rabin, L. (2016). The effect of listening experience on the discrimnatinon of $/ \mathrm{ba} / \mathrm{and} / \mathrm{pa} /$ in Hebrew-learning and Arabic-learning infants. Infant Behavior and Development, 42, 86-99. https://doi.org/10.1016/j.infbeh.2015.10.002

Setter, J., \& Jenkins, J. (2005). Pronunciation. State-of-the Art Article. Language Teaching, 38, 1-17. https://doi.org/10.1017/S026144480500251X

Shalchian, S., Vahdany, F., \& Arjmandi, M. (2014). The effect of using reading aloud on improving Iranian EFL learners' pronunciation of word stress. Modern Journal of Language Teaching Methods (MJLTM), 4(2).

Tantanit, T. (2013). Pronunciation problems of third year students in allied science at Thammasart University. Proceedings of the 51th Thammasart University Academic Conference, 170-177.

Tuaycharoen, P. (1990). Phonetics and practical phonetics. Bangkok: Thammasat University Press (In Thai).

Vandergrift, L. (1999). Facilitating second language listening comprehension: acquiring successful strategies. ELT Journal, 53, 168-176. https://doi.org/10.1093/elt/53.3.168

Vitanova, G., \& Miller, A. (2002). Reflective practice in pronunciation learning. The Internet TESL Journal, 8(1). Retrieved April 1, 2017, from http://iteslj.org

Wei, Y., \& Zhou, Y. (2002). Insight into English Pronunciation Problems of Thai Students. The Annual Meeting of the Quadruple Helix. Retrieved March 15, 2015, from http://files.eric.ed.gov/fulltext/ED476746.pdf

Wilson, J. (2009). How to teach listening. Essex, England: Pearson Longman.

\section{Copyrights}

Copyright for this article is retained by the author(s), with first publication rights granted to the journal.

This is an open-access article distributed under the terms and conditions of the Creative Commons Attribution license (http://creativecommons.org/licenses/by/4.0/). 